\author{
Ліпова О.Л. \\ старший викладач \\ E-mail: lipovaolga@ukr.net \\ Черевата T.M. \\ кандидат сільськогосподарських наук, доцент \\ кафедра маркетингу, підприємництва і торгівлі \\ Одеська національна академія харчових технологій \\ вул. Канатна,112 м. Одеса, Україна, 65039 \\ E-mail: $\underline{\text { t cherevataya@ukr.net }}$
}

\title{
АДАПТИВНІСТЬ ЯК КЛЮЧОВИЙ ФАКТОР КОНКУРЕНТОСПРОМОЖНОСТІ ПІДПРИЕМСТВА
}

В статті розглянуто та обґрунтовано закономірний взаємозв'язок ринкових категорій «адаптивність підприємства» та «конкурентоспроможність підприємства», досліджено прикладний аспект щодо етапів адаптаційного процесу підприємства.

В статті визначено актуальність адаптаційного процесу підприємства як основи розвитку його конкурентоспроможності. Уточнено визначення категорії «адаптивність підприємства» як здатність, можливість та швидкість його реагування на зміни та виклики, що відбуваються як у зовнішньому середовищі, так і у внутрішніх умовах господарювання. Запропоновано рекомендації практичної адаптації суб'єктів господарювання. Акцентовано увагу на різновидах стану адаптивності. Розроблено послідовність етапів адаптації в контексті турбулентної економіки.

Ключові слова: адаптація, адаптивність і адаптованість підприємства, адаптаційний процес, адаптаційний механізм, конкурентоспроможність підприємства.

\section{This work is licensed under a Creative Commons Attribution 4.0 International License} http://creativecommons.org/licenses/by/4.0/

Постановка проблеми та її зв'язок з важливими науковими та практичними завданнями. В умовах розбудови ринкової економіки України, якій притаманні глобалізація економічного розвитку та загострення конкурентної боротьби, зростає необхідність оптимального, активного та оперативного реагування підприємства до зовнішніх змін та викликів, які спричинені різними мінливими чинниками в певних сферах життєдіяльності суспільства, що в будь-якій мірі торкаються можливості стабільного функціонування підприємств. За таких умов функціонування саме адаптація, адаптивність та адаптованість гарантують підприємству розширення діапазону його ринкових можливостей:

- від здатності уникати кризових явищ в будь-якій сфері його діяльності;

- до можливості ефективно конкурувати.

Альтернативою адаптаційного пристосування $€$ втрата підприємством гнучкості, здатності реагувати на вплив факторів оточення, і як результат - втрата конкурентоспроможності та стратегічної стійкості.

Адаптивність та конкурентоспроможність підприємства тісно пов'язані як в теоретичному, так і в прикладному сенсі: вони взаємообумовлені і знаходяться в прямій функціональній взаємозалежності: 3 одного боку, тільки конкурентоспроможне підприємство може бути оптимально адаптоване до змін, створивши через накопичення конкурентних переваг певний потенціал своєї економічної, інвестиційної та фінансової стабільності, а $з$ другого боку, тільки підприємство, що здатне оптимально реагувати на змі -

ни, має бути ймовірність максимально результативним і в конкурентному середовищі.

Адаптація підприємства до умов зовнішнього середовища - надзвичайно складний процес, тому питання дослідження адаптаційного процесу та його вплив на конкурентоспроможність підприємства набувають особливої актуальності. Саме адаптаційні можливості підприємства та рівень його поточної адаптованості до мінливості зовнішнього середовища зумовлюють його стратегічну стійкість та високий рівень конкурентоспроможності в довготривалій перспективі, чим і зумовлена актуальність теоретичних досліджень у визначеній сфері.

Аналіз останніх публікацій по проблемі. Стан проблеми адаптивності підприємства в ринкових умовах постійно вивчається на всіх рівнях, вона зосереджена в багатьох наукових працях українських та іноземних авторів. Окремі аспекти процесу адаптації досліджені у роботах Н. Білошкурської [1], Л.Донець [2], В.Ячменьової та 3.Османової [4].

Проблеми адаптивності підприємства досліджуються у наукових роботах таких вченихекономістів, як Д. Андресен, І. Ансофф, В. Васильєв, Дж. Діксон, Б. Жуков, Б. Мільнер, А. Покровський, Т. Садовська, П. Сегне, В. Самочкін, В. Стівенсон, О. 
Туровець, які наголошують, що адаптивність, перш за все, пов'язана 3 еволюційним характером розвитку підприємства і спрямована на забезпечення його ефективності в довгостроковому періоді, в т.ч. і в конкурентній боротьбі.

Аналіз зовнішнього середовища розглянуто у роботах Н.П. Міщенка[3]. Як відмічають Охтень А.А. та О. Р. Виноградова, поняття адаптації було запозичене $з$ біології технічними та економічними науками [5].

Один із найбільш відомих теоретиків маркетингу Ф. Котлер наголошує: «Спеціалісти маркетингу повинні приділяти особливу увагу тенденціям і процесам розвитку компонентів зовнішньої середи та за необхідності пристосовувати стратегії маркетингу до них» [9].

Подальші наукові пошуки у цій сфері можуть бути зосереджені на прикладному аспекті та дослідженні етапів адаптаційного процесу.

Формулювання цілей дослідження. Мета даного дослідження - теоретичне обгрунтування закономірного і безумовного взаємозв'язку ринкових категорій «адаптивність» $\mathrm{i}$ «конкурентоспроможність», також прикладного значення кожного з етапів адаптаційного процесу.

Сприйнятливість до змін та викликів стає ключовим фактором підвищення конкурентоспроможності суб'єктів господарювання та національної економіки в цілому. Тому особливого значення в сучасних умовах набуває необхідність формування цілісної системи адаптації підприємства 3 акцентом на етапи практичної адаптації підприємства.

Виклад основних результатів та їх обгрунтування. Світова економіка перебуває в трансформаційному стані, головною характеристикою якого $\epsilon$ глобалізація як якісно нового етапу розвитку інтернаціоналізації господарського життя та прискорення динаміки глобальних перманентних процесів. Динамічно змінюється більшість соціально-економічних інститутів як у світовому масштабі, так і в межах окремих суспільств. В умовах мінливості сучасного світу жодна організаційна система, що функціонує, не може залишатися осторонь змін, які відбуваються в усіх сферах людської життєдіяльності.

Підприємство $є$ відкритою соціальноекономічною системою, яка безпосередньо залежить від стану та динаміки змін в зовнішньому середовищі. Активне, нестабільне та невизначене зовнішнє середовище $\epsilon$ головною та первинною умовою його функціонування. Залежність підприємств від ділових партнерів, фіскальних органів, владних структур, законодавчої бази, поведінки власників та інвесторів, конкурентів, а також динамічність зміни внутрішніх умов господарювання сприяє виникненню певних загроз та ризиків, що впливає на рівень економічної безпеки підприємства та зумовлює необхідність його адаптивної реакції з метою забезпечення збалансованого розвитку, а саме:

- постійної уваги та реакції на зміни ринкового оточення, коректності в оцінці змін, що відбуваються;
- проявів нового економічного мислення при змінах у внутрішньому середовищі на основі пристосування планів і прогнозів, структур і способів організації виробництва, окремих напрямків функціонування до нових вимог зовнішнього середовища 3 використанням адекватних методів моделювання, прогнозування, поглибленого аналізу, економічної діагностики, вдосконалення форм і методів господарювання;

- дотримання оптимальної стратегії розвитку. При цьому суб'єкти господарювання вимушені не тільки активно адаптуватися, але водночас результативно конкурувати на ринку, щоб підтримувати певний рівень прибутковості. Особливого значення за таких умов набуває їх здатність до адаптації.

На думку автора, під адаптацією розуміється така реакція організаційної системи на зміну умов діяльності, яка протидіє можливому зниженню якості іiі функціонування.

Поняття адаптивної системи тісно пов'язане 3 категорією системи, яка може самоорганізуватися, здатної до упорядкування елементів системи за рахунок внутрішніх факторів, без зовнішнього впливу [9]. Поняття адаптованої системи визначає такий iї стан, що характеризує іiї адекватну реакцію на останні зміни в зовнішньому середовищі.

Таким чином, адаптація розглядається як процес, що є необхідним для забезпечення ефективного функціонування підприємства і його елементів в нових умовах, орієнтованих на зміни зовнішнього та внутрішнього середовища. Вона передбачає можливі зміни в структурі підприємства, в управлінні та у його функціональних процесах. Такий процес являє собою організацію взаємодії підприємства 3 факторами зовнішнього середовища, метою якої $\epsilon$ досягнення балансу між внутрішнім та зовнішнім середовищем.

Проблеми та складність адаптації підприємств України до ринкових умов пов'язані з двома основними напрямками змін зовнішнього середовища:

- наявність мінливість і невизначеність зовнішнього оточення підприємства, безперервне виникнення нових тенденцій у розвитку економіки та суспільства, прискорення науково-технічного прогресу, перехід сучасного суспільства до інноваційного типу розвитку;

- активізація процесу реформування в Україні, що пов'язаний зі змінами форм власності та структурними змінами в економіці. Реформаторські заходи створюють принципово нове зовнішне середовище господарювання, яке значно відрізняється від радянського.

Між зазначеними напрямками змін в зовнішньому середовищі існує тісний логічний зв'язок, a їх одночасний вплив значно ускладнює процес адаптації підприємства до мінливих ринкових вимог. Проте зміни умов господарювання не лише ускладнюють діяльність підприємства, але й відкривають нові перспективи для його розвитку, закладають 
основи для нарощування потенціалів його конкурентної стійкості.

Зовнішнє середовище не є безмежним для конкретного підприємства, воно обмежується в залежності від цілей підприємства. Але в ньому завжди виділяються певні системи: суспільно-політична, економічна та екологічна, які можуть в різний час або одночасно впливати на стабільність функціонування підприємства, тобто створювати багатовекторність проблем та загроз і спонукати його до адаптивної реакції щодо активізації певного адаптивного механізму, що запускає в дію адаптивні процеси всередині підприємства за наявності у нього певного рівня адаптивних можливостей.

Кожна з систем зовнішнього середовища характеризується сукупністю факторів прямого та непрямого впливу, які можуть впливати на підприємство на різних рівнях: на міжнародному, національному, регіональному рівнях та в межах ділового оточення підприємства - та викликати необхідність реагування на них.

Фактори прямого впливу безпосередньо впливають на діяльність підприємств, які, в свою чергу, відчувають на собі аналогічний вплив через зміну умов співпраці 3 постачальниками, зі споживачами, 3 посередниками, 3 конкурентами або через зміну умов державного регулювання економіки, що вимагає від підприємства оперативних професійних рішень для досягнення відповідності внутрішнього середовища вимогам ринку.

Фактори непрямого впливу можуть не здійснювати безпосередній вплив на підприємство, але 3 часом все ж таки позначаються на його діяльності. Вони виникають в макроекономічній, соціальнокультурній, природній, науково-технічній, демографічній сферах суспільства.

Внутрішнє середовище підприємства визначається відношенням осіб, які прямо зацікавлені в певних результатах господарювання, до підприємства та відносинами між собою. Такими елементами внутрішнього середовища підприємства можуть бути окремі робітники, власники, формальні та неформальні групи, підрозділи та підсистеми, створені для здійснення спеціалізованих функцій: кадрова, виробнича, збутова, управлінська, інформаційна.

Можна також виділити елементи в організаційній структурі підприємства, збереження яких за будь-яких змін $є$ обов'язковою умовою успішної адаптації підприємства до ринкових перетворень: цілі та стратегія підприємства на ринку, виробничотехнологічна база, організаційна структура, кадровий персонал.

Таким чином, адаптація - це пристосування функціонуючої системи до зміни певних суттєвих умов ㄲï функціонування, а також головний критерій ефективності в конкуренції. Адаптація не тотожна адаптивності. Адаптивність - це здатність підприємства своєчасно та активно реагувати на зміни у зовнішньому середовищі, що $є$ однією із вагомих причин їх комерційного успіху та високого рівня конкурентоспроможності в умовах ринку. Адаптоване підприємство потенційно підвищує рівень своїх конкурентних переваг. Тому адаптивність підприємства можна вважати інструментом, за допомогою якого формується високий рівень його конкурентоспроможності.

Таким чином, процес адаптації підприємства до змін та процес підвищення рівня його конкурентоспроможності пов'язані між собою причинонаслідковим та прямим функціональним зв'язком; вони відбуваються одночасно через активізацію одних і тих же умов.

Механізм адаптації підприємства, що є сукупністю принципів, інструментів і технологій прийняття й виконання управлінських рішень, заснований на постійному відстеженні відповідності фактичного рівня адаптації нормативному (або бажаному), вносить своєчасні зміни в стратегічні, поточні та оперативні плани з метою забезпечення не тільки виживання підприємства, а також для досягнення і зміцнення його конкурентних позицій на ринку. Дія адаптивного механізму підприємства відбувається таким чином. У певний момент часу підприємство знаходиться в певному оптимальному стані, відповідному стану зовнішнього середовища. Між підприємством і зовнішнім середовищем існує двосторонній зв'язок. Під час переходу зовнішнього середовища в інший стан, який торкається умов функціонування підприємства, відбувається вплив чинників на механізм такого двостороннього зв'язку, що позначається на стані підприємства. Підприємство за таких умов переходить в інший стан, який, з великою мірою вірогідності, знаходиться за межами оптимального. При адаптивній системі управління спрацьовує механізм адаптації, що пристосовує підприємство до нових умов зовнішнього середовища так, щоб в цих умовах підприємство функціонувало оптимально, забезпечуючи стабільність функціонування на ринку та підтримку й розвиток вже досягнутого рівня конкурентоспроможності.

Рівень чутливості підприємства, який характеризує ступінь залежності підприємства від змін зовнішнього та внутрішнього середовища, залежить від рівня адаптивності (здатності та гнучкості в пристосовуванні до змін) окремих структур підприємства, тобто спроможності підприємства до перерозподілу або активізації ресурсів для досягнення оптимальних результатів господарювання в умовах змін ринкового оточення, а також ступінь інтеграції та узгодженості дій підрозділів підприємства 3 узгодженням нагальних завдань підприємства.

Скорочення періоду адаптації (адаптаційного синдрому) підприємства може позитивно вплинути на стійкі суттєві характеристики підприємства, а також на рівень його конкурентоспроможності.

Виходячи з того, що адаптація є складним багатоаспектним процесом, розподіл практичних адаптивних функцій між структурними підрозділами 
підприємства в процесі комплексної системної адаптації підприємства, а також щодо розвитку його кон- курентних потенціалів нами вбачається так, як відображено в табл. 1.

Таблиця 1

Систематизація адаптивних функції підприємства в межах адаптаційного процесу*

\begin{tabular}{|c|c|c|}
\hline $\begin{array}{c}\text { Структурний } \\
\text { підрозділ або категорія } \\
\text { персоналу } \\
\end{array}$ & Розподіл узагальнених адаптивних функції & $\begin{array}{l}\text { Оптимальні напрямки внутріш- } \\
\text { ньої адаптації підприємства }\end{array}$ \\
\hline Топ-менеджери & $\begin{array}{l}\text { - аналіз відповідності внутрішнього середови- } \\
\text { ща зовнішнім умовам господарювання; } \\
\text { - визначення змін в зовнішньому середовищі, } \\
\text { оперативна реакція на найбільш значимі зміни } \\
\text { для підприємства; } \\
\text { - виявлення причинно-наслідкових зв’язків між } \\
\text { впливом зовнішніх чинників та наслідковими } \\
\text { явищами та процесами; } \\
\text { - свідоме управління адаптивними змінами на } \\
\text { підприємстві; } \\
\text { - створення оптимальних багатоваріантних сце- } \\
\text { наріїв еволюції адаптаційних дій та розвитку } \\
\text { подій; } \\
\text { - прогнозування перспектив розвитку зовніш- } \\
\text { нього та внутрішнього середовища }\end{array}$ & $\begin{array}{l}\text { - активізація інноваційних та ін- } \\
\text { вестиційних процесів }\end{array}$ \\
\hline Маркетингова служба & $\begin{array}{l}\text { - створення та ефективне використання системи } \\
\text { моніторингу зовнішнього конкурентного сере- } \\
\text { довища; } \\
\text { - оперативна реакція на зміни в конкурентному } \\
\text { середовищі; } \\
\text { - якісне дослідження конкурентного потенціа- } \\
\text { лу підприємства }\end{array}$ & $\begin{array}{l}\text { - оптимізація товарного асорти- } \\
\text { менту; } \\
\text { - скорочення товарних запасів }\end{array}$ \\
\hline Економічна служба & $\begin{array}{l}\text { - якісне дослідження економічного потенціалу } \\
\text { підприємства; } \\
\text { - системний аналіз рівня ефективності адапта- } \\
\text { ційних заходів }\end{array}$ & $\begin{array}{l}\text { - контроль за забезпеченням } \\
\text { ефективності використання всіх } \\
\text { ресурсів; } \\
\text { - оптимізація затратного механі- } \\
\text { зму; } \\
\text { - оптимізація ціноутворення } \\
\end{array}$ \\
\hline Менеджери & $\begin{array}{l}\text { - визначення оптимальної альтернативи із су- } \\
\text { купності можливих реакцій на зміни; } \\
\text { - розробка конкретних пропозицій щодо плану } \\
\text { адаптації структурного підрозділу }\end{array}$ & $\begin{array}{l}\text { - удосконалення принципів, ме- } \\
\text { тодів та способів управління пер- } \\
\text { соналом та процесами }\end{array}$ \\
\hline $\begin{array}{l}\text { Спеціалісти } \\
\text { підрозділів }\end{array}$ & $\begin{array}{l}\text { - надання своєчасних професійних рекоменда- } \\
\text { цій щодо реагування на підприємницькі ризики; } \\
\text { - практичне впровадження найефективніших } \\
\text { адаптаційних організаційно-економічних захо- } \\
\text { дів з розробкою адаптаційного кошторису }\end{array}$ & $\begin{array}{l}\text { - активна та оперативна участь в } \\
\text { адаптаційних заходах }\end{array}$ \\
\hline Кадрова служба & $\begin{array}{l}\text { - розробка системи мотивації персоналу до ефе- } \\
\text { ктивних змін }\end{array}$ & $\begin{array}{l}\text { - удосконалення методів, прин- } \\
\text { ципів та способів підбору та від- } \\
\text { бору професійно компетентного } \\
\text { персоналу при формуванні кад- } \\
\text { рового складу підприємства }\end{array}$ \\
\hline $\begin{array}{l}\text { Інженерно- } \\
\text { технологічні служби } \\
\text { та виробничі } \\
\text { підрозділи }\end{array}$ & $\begin{array}{l}\text { - технологічне та технічне оновлення, модерні- } \\
\text { зація виробництва; } \\
\text { - підвищення якості продукції. }\end{array}$ & - виконання планових завдань \\
\hline $\begin{array}{l}\text { Юридична } \\
\text { служба }\end{array}$ & $\begin{array}{l}\text { - пропозиція варіантів оптимального реагування } \\
\text { підприємства на зміни в рамках «правового по- } \\
\text { ля» }\end{array}$ & $\begin{array}{l}\text { - оперативна реакція на зміни в } \\
\text { діючому законодавстві (в тій йо- } \\
\text { го частині, що безпосередньо } \\
\text { стосується функцій підприємст- } \\
\text { ва) }\end{array}$ \\
\hline
\end{tabular}

* авторська розробка 
Графічно адаптацію підприємства можна уявити як двосторонній зустрічний процес, в якому, 3 зміну. При адекватній реакції досягається максимально можливий рівень балансу інтересів всіх сторін процесу та узгодженості при вирішенні проблеми.

В прикладному сенсі адаптація як складний одного боку, відбувається зміна умов діяльності підприємства, а з іншого - реакція підприємства на таку та системний процес має певну послідовність етапів iii реалізації, в кожному з яких може бути задіяний різний інструментарій, що детально відображено в табл.2.

Таблиця 2

Етапи реалізації адаптаційного процесу*

\begin{tabular}{|c|c|c|c|c|}
\hline $\begin{array}{c}\text { Послідов- } \\
\text { ність етапів } \\
\text { адаптаційно- } \\
\text { го процесу }\end{array}$ & $\begin{array}{l}\text { Назва етапу } \\
\text { адаптації }\end{array}$ & Мета етапу & $\begin{array}{l}\text { Зміст етапу } \\
\text { адаптації }\end{array}$ & $\begin{array}{c}\text { Інструменти } \\
\text { адаптаційного } \\
\text { процесу } \\
\end{array}$ \\
\hline 1 & $\begin{array}{l}\text { Аналіз стану і ди- } \\
\text { наміки суттєвих фак- } \\
\text { торів зовнішнього } \\
\text { середовища }\end{array}$ & $\begin{array}{l}\text { Виявлення рівня та } \\
\text { ступеню нестабіль- } \\
\text { ності зовнішнього } \\
\text { середовища } \\
\text { Виявлення рівня по- } \\
\text { точної адаптивності } \\
\text { підприємства }\end{array}$ & $\begin{array}{l}\text { Постійне відстежен- } \\
\text { ня (моніторинг) або } \\
\text { спеціально організо- } \\
\text { ване дослідження } \\
\text { факторів зовнішньої } \\
\text { середовища }\end{array}$ & $\begin{array}{l}\text { PEST-аналіз; SWOT- } \\
\text { аналіз; ЕTOM-аналіз; } \\
\text { QUEST-аналіз; } \\
\text { Експерт-аналіз }\end{array}$ \\
\hline 2 & $\begin{array}{l}\text { Аналіз співпадіння } \\
\text { внутрішнього середо- } \\
\text { вища вимогам зовні- } \\
\text { шнього середовища } \\
\text { та визнання необхід- } \\
\text { ності адаптаційних } \\
\text { заходів при виявленні } \\
\text { неспівпадіння }\end{array}$ & $\begin{array}{l}\text { Виявлення зони не- } \\
\text { стабільності }\end{array}$ & $\begin{array}{l}\text { Дослідження внут- } \\
\text { рішньої середовища } \\
\text { підприємства, вияв- } \\
\text { лення проблем в йо- } \\
\text { го діяльності, іден- } \\
\text { тифікація факторів } \\
\text { оточення, що спри- } \\
\text { чиняють проблеми }\end{array}$ & $\begin{array}{l}\text { Аналіз виробничо- } \\
\text { господарської } \\
\text { діяльності } \\
\text { Маркетингові дослі- } \\
\text { дження } \\
\text { Аналіз рівня ресурс- } \\
\text { ного забезпечення }\end{array}$ \\
\hline 3 & $\begin{array}{l}\text { Аналіз готовності до } \\
\text { змін та рівня адапти- } \\
\text { вності підприємства }\end{array}$ & $\begin{array}{l}\text { Отримання узагаль- } \\
\text { нюючої } \\
\text { оцінки ділових про- } \\
\text { фесійних характери- } \\
\text { стик керівництва, яка } \\
\text { впливає на здатність } \\
\text { підприємства сприй- } \\
\text { мати зміни та адек- } \\
\text { ватно реагувати на } \\
\text { них }\end{array}$ & $\begin{array}{l}\text { Аналіз визначеності } \\
\text { цілей діяльності, } \\
\text { наявності стратегій } \\
\text { розвитку та страте- } \\
\text { гічного мислення } \\
\text { Аналіз } \\
\text { рівня гнучкості підп- } \\
\text { риємства }\end{array}$ & $\begin{array}{l}\text { Експертне опитуван- } \\
\text { ня менеджерів вищої } \\
\text { та середньої ланки }\end{array}$ \\
\hline 4 & 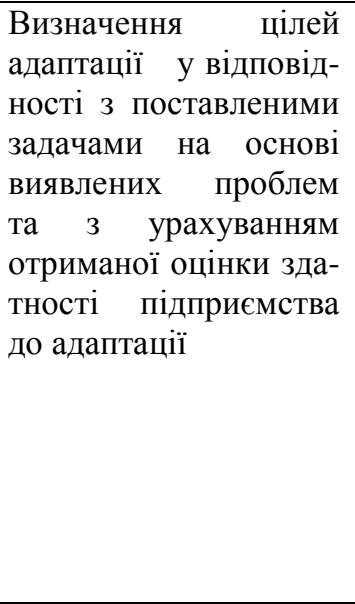 & $\begin{array}{l}\text { Аналіз рівня кількіс- } \\
\text { них та якісних пока- } \\
\text { зників } 3 \text { метою ви- } \\
\text { значення їх відповід- } \\
\text { ності нормативному } \\
\text { або бажаному рівню }\end{array}$ & $\begin{array}{l}\text { Розрахунок кількіс- } \\
\text { них та якісних пока- } \\
\text { зників }\end{array}$ & $\begin{array}{l}\text { Кількісні індикатори } \\
\text { : } \\
\text { - рівень рентабельно- } \\
\text { сті продукції та про- } \\
\text { дажів, } \\
\text { - частка ринку, } \\
\text { - обсяги реалізації. } \\
\text { Якісними цілями є: } \\
\text { підвищення рівня } \\
\text { конкурентоспромож- } \\
\text { ності підприємства } \\
\text { через підвищення } \\
\text { економічної та фінан- } \\
\text { сової стійкості, гнуч- } \\
\text { кості, адаптивності }\end{array}$ \\
\hline 5 & $\begin{array}{l}\text { Стратегічний етап } \\
\text { адаптації }\end{array}$ & $\begin{array}{l}\text { Визначення місця під- } \\
\text { приємства в адапта- } \\
\text { ційному просторі, } \\
\text { обгрунтування варіан- } \\
\text { ту стратегії адаптації }\end{array}$ & $\begin{array}{l}\text { Вибір стратегії адап- } \\
\text { тації }\end{array}$ & $\begin{array}{l}\text { Інтегральний показ- } \\
\text { ник адаптивності }\end{array}$ \\
\hline
\end{tabular}


Продовження табл. 2

\begin{tabular}{|c|c|c|c|c|}
\hline $\begin{array}{c}\text { Послідовність } \\
\text { етапів } \\
\text { адаптаційного } \\
\text { процесу }\end{array}$ & $\begin{array}{l}\text { Назва етапу } \\
\text { адаптації }\end{array}$ & Мета етапу & $\begin{array}{c}\text { Зміст етапу } \\
\text { адаптації }\end{array}$ & $\begin{array}{c}\text { Інструменти } \\
\text { адаптаційного процесу }\end{array}$ \\
\hline 1 & $\begin{array}{l}\text { Підготовчий } \\
\text { етап адаптації }\end{array}$ & $\begin{array}{l}\text { Підготовка до вті- } \\
\text { лення заходів через } \\
\text { визначення ресурс- } \\
\text { ного забезпечення }\end{array}$ & $\begin{array}{l}\text { Вибір напрямків } \\
\text { адаптації відбуваєть- } \\
\text { ся на основі постав- } \\
\text { лених задач адапта- } \\
\text { ції та вибраної } \\
\text { стратегії }\end{array}$ & $\begin{array}{l}\text { Активізація та мотива- } \\
\text { ція персоналу до опе- } \\
\text { ративного впрова- } \\
\text { дження обраного на- } \\
\text { прямку адаптації }\end{array}$ \\
\hline 7 & $\begin{array}{l}\text { Практичний етап } \\
\text { реалізації адаптації }\end{array}$ & $\begin{array}{l}\text { Завершення адапта- } \\
\text { ційного процесу }\end{array}$ & $\begin{array}{l}\text { Впровадження та } \\
\text { реалізація адапта- } \\
\text { ційних заходів }\end{array}$ & $\begin{array}{l}\text { Організаційне забезпе- } \\
\text { чення втілення заходів: } \\
\text { - призначення центру } \\
\text { керівництва адаптацій- } \\
\text { ним заходом, відпові- } \\
\text { дальних посадових } \\
\text { осіб, розподіл ресур- } \\
\text { сів між виконавцями }\end{array}$ \\
\hline 8 & $\begin{array}{l}\text { Завершальний } \\
\text { етап адаптації }\end{array}$ & $\begin{array}{l}\text { Визначення рівня } \\
\text { економічної доціль- } \\
\text { ності адаптаційного } \\
\text { заходу }\end{array}$ & $\begin{array}{l}\text { Аналіз економічної } \\
\text { ефективності адап- } \\
\text { таційних заходів }\end{array}$ & $\begin{array}{l}\text { Порівняння результатів } \\
\text { впровадження заходу } 3 \\
\text { витратами на його ор- } \\
\text { ганізацію та впрова- } \\
\text { дження }\end{array}$ \\
\hline
\end{tabular}

* авторська розробка

Як видно $з$ табл. 1 і 2, в практичній діяльності підприємства окремі заходи з адаптації підприємства створюють складний, майже безперервний комплексний та системний адаптаційний процес в умовах, коли існує необхідність постійного реагування та пристосування до мінливих умов господарювання. А кожний етап адаптації має свою логічну послідовність, інструментарій та особливості проведення.

Адаптаційний процес є потужним мотивуючим чинником до максимальної активізації всіх структурних підрозділів, всіх категорій персоналу до оперативних професійних дій та до ефективного використання всіх ресурсів підприємства.

$€$ доцільним проводити оцінку адаптивності підприємства комплексно та одночасно за такими напрямками: організаційний, трудовий, інвестиційний, інноваційний, виробничий, фінансовий, законодавчий та інформаційний.

Процес адаптації підприємства та процес підвищення рівня його конкурентоспроможності пов'язані між собою причино-наслідковим зв'язком та відбуваються на підприємстві одночасно за одними й тими ж напрямками та через використання одних й тих же ресурсів підприємства.

Таким чином, усвідомлення керівництвом підприємств необхідності оперативної комплексної адаптації, особливостей етапів іiї здійснення, коректний розподіл повноважень і посадових обов'язків при ефективному управлінні адаптаційним процесом формує базис та $\epsilon$ ключовим фактором для забезпечення ефективного функціонування суб'єкта господарювання, формує достатній рівень його адаптивності, а відтак і його конкурентоспроможності.
Висновки та перспективи подальших досліджень. В умовах турбулентної економіки, нестабільності ринку, прискорення динаміки суспільнополітичних, економічних процесів і переходу сучасного суспільства до інноваційного типу розвитку зміни умов господарювання відбуваються майже безперервно, а необхідність реакції підприємства на зовнішні виклики стає для нього обов'язковою та створює підгрунтя для лідерства в конкурентному середовищі. За таких умов здатність сучасного підприємства до адекватної адаптації стала основою його довготривалого сталого життєвого циклу, ключовим чинником комерційного та конкурентного успіху.

Адаптивність, таким чином, характеризує готовність до адаптації та швидкість реакції підприємства на виклики та зміни. Це кінцевий стан процесу пристосування підприємства до викликів зовнішнього середовища за умов досягнення ним тимчасової відповідності умовам зовнішнього середовища.

В прикладному сенсі адаптивність підприємства може розглядатися як засіб профілактики кризових явищ в діяльності підприємства, інструментом щодо зниження підприємницьких ризиків, підвищення економічної безпеки, раціонального та ефективного використання ресурсів, забезпечення сталого функціонування, а найголовніше, заходом забезпечення його конкурентоспроможності.

Найбільш ефективним напрямком вирішення цього завдання $є$ формування та розвиток цілісного безперервного еволюційного процесу адаптації підприємства, який безпосередньо формує рівень адаптивності підприємства, перетворює його на адаптивну та певній мірі адаптовану систему та $є$ дієвим на всіх стадіях життєвого циклу підприємства. 


\title{
Література
}

1. Білошкурська Н. В. Моделі адаптивної поведінки та їх роль у формуванні економічної безпеки підприємства / Н. В. Білошкурська // Актуальні проблеми економіки. - 2010. - № 12 (114). - С. 101-104.

2. Донець Л. І. Економічна безпека підприємства: [навч. посібник] / Л. І. Донець, Н. В. Ващенко. - К.: Центр навчально літератури, 2008. - 240 с.

3. Міщенко А. П. Стратегічне управління: [навч. посібник] / А. П. Міщенко. - К.: Центр навчальної літератури, 2014. - $336 \mathrm{c}$.

4. Ячменьова В. М. Сутність понять «адаптація» та «адаптивність» [Електронний ресурс] / В. М. Ячменьова, 3. О. Османова // Вісник Національного університету «Львівська політехніка». - 2010. - № 684. - С. 346353. - Режим доступу:

http://www.nbuv.gov.ua/portal/natural/VNULP/Ekonomika/2010_684/71.pdf.

5. Охтень А. А. Теоретические основы адаптивного планирования производства / А. А. Охтень, О. Р. Виноградова // Науковий вісн. ЧДІЕУ. - 2009. -№ 3 (4). - С. 101-107.

6. Энциклопедия кибернетики: [в 2 т.]. - К. : Гл. ред. укр. сов. энцикл., 1975. - 607 с.

7. Срагович В. Г. Адаптивное управление / В. Г. Срагович. - М.: Наука, 1981. - 384 с.

8. Эшби У. Р. Введение в кибернетику / У. Р. Эшби ; [пер. с англ.] - М.:

Изд-во иностр. лит., 1959. - 432 с.

9. Kotler P. Marketing Management / Philip Kotler, Kevin Lane Keller. - 14th ed. -Pearson Education Limited, 2012. -817 p.

10.Economic dictionary (2017). Retrieved from mirslovarei.com/content_eco/.

Стаття надійшла 9.01.2018

Стаття прийнята до друку 23.01.2018 Доступно в мережі Internet 31.03.2018

\author{
Липова О.Л. \\ старший преподаватель \\ E-mail: lipovaolga@ukr.net \\ Череватая T.M. \\ кандидат сельскохозяйственных наук, доцент \\ кафедра маркетинга, предпринимательства и торговли \\ Одесская национальная академия пищевых технологий \\ ул. Канатная, 112, г. Одесса, Украина, 65039 \\ E-mail: t cherevataya@ukr.net
}

\section{АДАПТИВНОСТЬ КАК КЛЮЧЕВОЙ ФАКТОР КОНКУРЕНТОСПОСОБНОСТИ ПРЕДПРИЯТИЯ}

Первоочередная цель статьи - обоснование закономерной и безусловной взаимосвязи рыночных категорий «адаптивность предприятия» и «конкурентоспособность предприятия». В прикладном аспекте предложен перечень этапов адаптационного процесса предприятия, цель, содержание и инструментарий каждого из них.

В статье исследована актуальность адаптационного процесса предприятия как основы развития его конкурентоспособности. Перечислены действенные фракторы, вызывающие необходимость адаптивных изменений для предприятия. Уточнена категория «адаптивность предприятия» как скорость реагирования предприятия на изменения, которые происходят как во внешней, так и во внутренней среде в период его функционировании на всех стадиях жизненного цикла. Предложены рекомендации практической адаптации субъектов хозяйствования к условиям внешней среды. Разработана последовательность этапов адаптации в контексте турбулентной экономики. Предложено проводить оценку адаптивности предприятия по таким функциям, как организационная, трудовая, инвестиционная, инновационная, производственная, финансовая, законодательная и информационная.

С учетом того, что достигнутый уровень адаптивности каждого отдельного предприятия является динамичной величиной и может изменяться во времени из-за изменения интенсивности и перечня влияния специфических фракторов объективного и субъективного характера, сделан смысловой акцент на различных видах ее состояния: предыдущий, текущий и перспективный.

Следует также учесть, что оценка уровня адаптивности предприятия и уровня его конкурентоспособности должна производиться на предприятии постоянно на всех этапах его функционирования.

Ключевые слова: адаптация, адаптивность предприятия, адаптационный процесс, адаптивный механизм предприятия, конкурентоспособность предприятия. 


\author{
Lipova 0. \\ Assistant \\ E-mail: lipovaolga@ukr.net \\ Cherevata T. \\ Ph.D., Associate Professor \\ Department of Marketing, Business and Trade \\ Odessa National Academy of Food Technologies \\ Kanatna str., 112, Odesa, Ukraine, 65039 \\ E-mail: t cherevataya@ukr.net
}

\title{
ADAPTIVENESS AS A KEY FACTOR OF COMPETITIVENESS OF AN ENTERPRISE
}

The top priority purpose of this article is the analysis and grounding of in disputable relationship of important marketing concepts "competitiveness of enterprises" and "adaptiveness of enterprises" and introduction of the list, purpose, content, instruments of each of the stage of the adaptive prosess of an enterprise.

The article analyses the relevance of the adaptive prosess of enterprises as the basis of development of enterprises competitiveness.

There are some effective factors causing the necessity of adaptive modifications for enterprises. The category of «adaptability of enterprises» is specified as the speed of response of enterprises to changes that take place both in external and internal environment in the course of its operation during all stages of the life cycle. The recommendations of economic entities practical adaptation to the conditions of external environment have been proposed. The sequence of adaptation stages in the terms of transitive economy is developed. It is suggested to assess the adaptability of the enterprises by the aspects such as: organizational, labor, investment, innovation, manufacturing, financial, legislative, informational.

Taking into account that the level of adaptability of each separate enterprise is a dynamic value and can be changed concerning time because of influence of specific factors of subjective and objective character, the semantic accent has been done on the types of its condition: previous, current and perspective.

It should also be taken into account that the estimation of adaptability level of each enterprise and competitiveness level of enterprises must be done constantly, at every stage of its functioning.

Keywords: adaptation, adaptiveness of enterprises, adaptation process, adaptation stages of enterprises, adaptation mechanism of enterprises, competitiveness of enterprises.

\section{References}

1. Biloshkurska, N. V. (2010). Modeli adaptyvnoi povedinky ta yikh rol u formuvanni ekonomichnoi bezpeky pidpryiemstva. Aktualni Problemy Ekonomiky, (12 (114)), 101-104.

2. Donets, L. I., \& Vashchenko, N. V. (2008). Ekonomichna bezpeka pidpryiemstva. K.: Tsentr navchalnoi literatury.

3. Mishchenko, A. P. (2014). Stratehichne upravlinnia. K.: Tsentr navchalnoi literatury.

4. Yachmenova, V. M., \& Osmanova, Z. O. (2010). Sutnist poniat «adaptatsiia» ta «adaptyvnist». Visnyk Natsionalnoho Universytetu «Lvivska Politekhnika», (684), 346-353. Retrieved from http://www.nbuv.gov.ua/portal/natural/VNULP/Ekonomika/2010_684/71.pdf

5. Ohten, A. A., \& Vinogradova, O. R. (2009). Eoreticheskie osnovyi adaptivnogo planirovaniya proizvodstva. Naukovyi Visnyk ChDIEU, (3 (4)), 101-107.

6. Entsiklopediya kibernetiki (Vol. 2). (1975). K.: Gl. red. ukr. sov. entsikl.

7. Sragovich, V. G. (1981). Adaptivnoe upravlenie. M.: Nauka.

8. Eshbi, U. R. (1959). Vvedenie v kibernetiku. M.: Izd-vo inostr. lit.

9. Kotler, P., \& Keller, K. L. (2012). Marketing Management (14th ed.). Pearson Education Limited.

10.Economic dictionary (2017). Retrieved from mirslovarei.com/content_eco/. 